\title{
Survival of cancer patients in Fujian, Southeast China: a population-based cancer registry study
}

\author{
Yan ZHOU ${ }^{1, *}$, Zhi-Sheng XIANG ${ }^{1, *}$, Jing-Yu MA', Yong-Tian LIN ${ }^{1}$, Yan-Ping CHEN², Hui-Juan JIANG ${ }^{1}$, Lin-Rong WU ${ }^{3}$, Chuan-Ben CHEN ${ }^{4, *}$ \\ ${ }^{1}$ Department of Epidemiology, Fujian Medical University Cancer Hospital, Fujian Cancer Hospital, Fuzhou, China; ${ }^{2}$ Department of Pathology, \\ Fujian Medical University Cancer Hospital, Fujian Cancer Hospital, Fuzhou, China; ${ }^{3}$ Fujian Medical University Cancer Hospital, Fujian Cancer \\ Hospital, Fuzhou, China; ${ }^{4}$ Department of Radiation Oncology, Fujian Medical University Cancer Hospital, Fujian Cancer Hospital, Fuzhou, \\ China
}

*Correspondence: chenchuanben2010@126.com

${ }^{*}$ Contributed equally to this work.

Received February 3, 2021 / Accepted April 7, 2021

\begin{abstract}
Survival rates are usually used to evaluate the effect of cancer treatment and prevention. No study has focused on the characteristic of population-based cancer survival in Fujian, which is regarded as one of the high-risk areas of cancer in China. This study aims to analyze the 5-year relative survival of patients in Fujian Province using population-based cancer registry data. A total of 8 population-based registries in Fujian Province reported cancer cases diagnosed in 2012-2014. Relative survival was calculated as the ratio between observed survival and expected survival. The 5-year relative survival for all cancers combined was $36.19 \%$ and the age-standardized 5-year relative survival for all patients was $31.80 \%$. Females had higher relative survival than males (38.90\% and $27.00 \%)$. The patients in urban areas had higher relative survival than those in rural areas (32.34\% and 31.29\%). Lung, gastric, liver, colorectal, and esophageal cancers were the five most common cancers, with 5 -year relative survival below $50 \%$. This is the first study that evaluated the population-based cancer relative survival in Fujian, China. Our study suggests that the overall survival of cancer patients in Fujian Province is poor. Furthermore, the results of this study can be used as a baseline for further research in Fujian, and provide important evidence for cancer etiology research.
\end{abstract}

Key words: relative survival, population-based cancer registry, cancer, Fujian

The burden of malignant tumors is increasing annually, and it has become a major public health problem worldwide, with high morbidity, disability, and mortality [1]. Various factors such as air pollution, unhealthy living habits, and pathological staging are considered to be associated with the morbidity and mortality of cancer [2,3]. Population-based cancer registries can routinely monitor the incidence, prevalence, and prognosis of cancer [4]. Relative survival is a key indicator to assess patient prognosis [5]. In 2015, a study first reported population-based cancer relative survival analyses in China, which showed that the 5-year relative survival of cancer was $30.9 \%$ [6]. The 5-year relative survival in China was far lower than that of the average level of other developed countries $[7,8]$. The study only covered $2 \%$ of the national population, and it might not accurately represent the survival of patients in other regions. Fujian Province is located in the southeast of China. In 1986, the first population-based malignant tumor registry in Fujian was established in Changle
County. The morbidity and mortality of cancer in Changle County have been published in the Cancer Incidence in Five Continents and Cancer Incidence and Mortality in China 2003-2007 [9, 10]. Currently, the incidence and mortality of cancer in Fujian Province are higher than the national average [11]. However, no study has assessed the overall survival of cancer in Fujian. Therefore, our study will summarize and analyze the follow-up data reported by each populationbased registry, and the first time to estimate the 5-year relative survival of cancer in Fujian. Our data can provide scientific evidences for cancer prevention and control.

\section{Materials and methods}

Study population and quality control. The populationbased cancer registration and follow-up project have been conducted in Fujian Province for more than 30 years. The county-level registries and local hospitals regularly report 
data to the Provincial Cancer Registry. The Fujian Provincial Cancer Registry is responsible for assessing, managing, and publishing the cancer data of Fujian, China. In our study, data on the subjects who were diagnosed with cancer during 2012-2014 were provided by the 8 Cancer Registries in Fujian Province. The topography, morphology, and behavior of cancer were encoded in accordance with the International Classification of Diseases for Oncology, $3^{\text {rd }}$ Edition (ICD-O-3) and the International Classification of Diseases 10th Revision (ICD-10). Using Guidelines for Chinese Cancer Registration and International Agency for Research on Cancer/International Association of Cancer Registries (IARC/IACR) to identify the impossible combinations between cancer site and morphology [12, 13]. Unusual cases were returned to local registries to verify the reality of the data. If a case was based on a death certificate only or the case had two or more primary malignant tumors, the case was excluded from our study.

Follow-up. Active and passive follow-up methods were used in all registries to determine the vital status of patients. The follow-up information for patients was updated until December 31, 2019. For the follow-up process, first, the staff of cancer registries routinely linked the vital surveillance database to cancer registration records. Then, for patients who had unmatched vital surveillance database, they or their families were followed up through several methods including telephone contacts and home visits.

Statistical analyses. Relative survival was used to evaluate patient prognosis. The relative survival was calculated as the ratio of the observed survival to the expected survival. Observed survival and expected survival were estimated using the life table method and the Ederer II method, respectively $[14,15]$. Each patient was stratified by period, sex, age group, and cancer site. Abridged life tables were smoothed to complete (single-year-of-age) life tables and extended to the age of 99 using the Elandt-Johnson method [16]. We classified patients into five major age groups (0-44, 45-54, 55-64, 65-74, and 75-99 years) according to the International Cancer Survival Standards (ICSS) for age standardization of survival. The age-standardized relative survival of most cancer was calculated according to the ICSS1 (0-44 years: 7\%), (45-54 years: $12 \%)$, (55-64 years: $23 \%),(65-74$ years: $29 \%)$, and (75-99 years: $29 \%$ ). The age-standardized relative survival of nasopharyngeal, melanoma of skin, cervix, brain, thyroid, and bone cancer was calculated according to the ICSS2 (0-44 years: 28\%), (45-54 years: 17\%), (55-64 years: $21 \%)$, (65-74 years: $20 \%)$, and (75-99 years: 14\%). For testicular cancer, the age-standardized relative survival of was calculated according to the ICSS3 (0-44 years: 60\%), (45-54 years: $10 \%),(55-64$ years: 10\%), (65-74 years: 10\%), and (75-99 years: $10 \%)$ [17]. Since all patients had undergone followup for 5 years, we used the classic cohort method to calculate the relative survival. According to the National Bureau of Statistics of China, areas in Fujian Province covered by cancer registries were classified into urban or rural. Descriptive statistics were analyzed using the SAS (version 9.2), and survival analyses were performed using the program of strs in Stata (version 12.0).

\section{Results}

Demographic characteristics. The demographic characteristics of the 8 cancer registries in Fujian Province are displayed in Table 1. During the study period, there were 33,649 newly diagnosed cancer patients. After excluding patients who registered the death certificate only $(2.81 \%)$ and patients who had multiple primary cancers $(2.11 \%)$, 31,989 patients were enrolled in the final study. Among these patients, there were 19,395 male patients and 12,594 female patients.

Relative survival of cancer. For all cancers combined, the 5 -year relative survival was $36.19 \%$ for patients diagnosed in Fujian in 2012-2014. The age-standardized 5-year relative survival for all patients was $31.80 \%$. Compared with males, females had a higher 5-year relative survival (38.90\% vs. $27.00 \%)$. In addition, the 5-year relative survival of cancer patients in urban areas was higher than that in rural $(32.34 \%$ vs. $31.29 \%$ ) (Table 2).

The age-standardized 5-year relative survival varied greatly according to the cancer type and sex. In males, the

Table 1. Characteristics of patients diagnosed with cancer between 2012 and 2014 in Fujian Province, China.

\begin{tabular}{|c|c|c|c|c|c|c|c|c|c|}
\hline \multirow[b]{2}{*}{ Registry } & \multirow[b]{2}{*}{ Area } & \multirow[b]{2}{*}{ Population } & \multirow{2}{*}{$\begin{array}{l}\text { Number } \\
\text { of patients }\end{array}$} & \multirow{2}{*}{$\begin{array}{c}\text { Median age } \\
\text { at diagnosis } \\
\text { (years) }\end{array}$} & \multirow{2}{*}{$\begin{array}{c}\text { Incidence } \\
\text { Rate } \\
(1 / 100,000)\end{array}$} & \multicolumn{2}{|c|}{ Exclusions (\%) } & \multirow{2}{*}{$\begin{array}{l}\text { Patients included } \\
\text { in analyses }\end{array}$} & \multirow{2}{*}{$\begin{array}{c}\text { Morphological } \\
\text { verified }(\%)\end{array}$} \\
\hline & & & & & & $\begin{array}{c}\text { Death } \\
\text { certificate only }\end{array}$ & $\begin{array}{l}\text { Multiple } \\
\text { primary }\end{array}$ & & \\
\hline Changle & Rural & 693,027 & 4,674 & 62 & 224.81 & 0.66 & 1.56 & 4,570 & 57.61 \\
\hline Xiamen & Urban & $1,326,549$ & 10,470 & 63 & 263.09 & 5.27 & 2.18 & 9,690 & 73.76 \\
\hline Tongan & Rural & 342,432 & 2,178 & 61 & 212.01 & 0.64 & 1.33 & 2,135 & 65.15 \\
\hline Xiangan & Rural & 311,039 & 2,197 & 60 & 235.45 & 6.05 & 2.37 & 2,012 & 69.78 \\
\hline Hanjiang & Urban & 438,724 & 4,505 & 63 & 342.28 & 0.59 & 1.39 & 4,415 & 71.31 \\
\hline Yongan & Rural & 327,620 & 2,501 & 63 & 254.46 & 2.72 & 2.16 & 2,379 & 65.78 \\
\hline Jianou & Rural & 544,281 & 3,740 & 60 & 229.05 & 0.61 & 1.52 & 3,660 & 53.63 \\
\hline Yongding & Rural & 489,663 & 3,384 & 61 & 230.36 & 2.98 & 4.58 & 3,128 & 73.41 \\
\hline All & Urban and rural & $4,473,335$ & 33,649 & 61 & 250.74 & 2.81 & 2.11 & 31,989 & 66.63 \\
\hline
\end{tabular}


5 -year relative survival was highest in the thyroid $(89.52 \%)$, testicular $(72.87 \%)$, and bladder (62.70\%) cancers, and lowest in pancreatic (6.49\%), liver (10.61\%), and lung (13.36\%) cancers. For females, the highest 5 -year relative survival was in the thyroid $(87.43 \%)$, breast $(70.37 \%)$, and uterine (68.66\%) cancers, while the lowest was pancreatic $(7.10 \%)$, liver $(11.65 \%)$, and lung $(19.33 \%)$ cancers. Female patients had better 5-year survival than the male patients for most cancers, except for bladder, bone, leukemia, and thyroid cancers (Table 3).

The composition of cancer indicated that the proportion of lung cancer was the highest, followed by gastric cancer, liver cancer, colorectal cancer, and esophageal cancer. The top five malignant tumors accounted for $62.15 \%$ of all cancers, with a 5 -year relative survival of $<50 \%$ in both sexes (Table 3 ). For these five common cancers, relative survival was different between urban and rural areas. Compared to rural areas, 5 -year relative survival of lung cancer and colorectal cancer in urban was lower. Conversely, the survival of stomach, liver, and esophageal cancers was higher in urban areas than in rural (Table 4). The relative survival of common cancers in both urban and rural decreased over time, and the relative survival of the males was always higher in urban areas than in rural (Figure 1).

For all cancers combined, a notable difference in survival existed in each age group. It was lowest at 75 years and older (19.45\%), followed by the 65-74-year age group (28.28\%). The youngest group had the highest relative survival (55.56\%). For the five most common cancers, the largest gap for survival among age groups was gastric cancer, with $39.69 \%$ in the $55-64$-year age group and $13.62 \%$ in the oldest age group. The smallest 5 -year relative survival difference was observed in liver cancer, but there was still a 9.43\% difference between the highest and lowest groups (Figure 2).

\section{Discussion}

So far as we know, our study is the first to systematically estimate the population-based cancer survival data in Fujian Province, Southeast China. The cancer registries are evenly located in the east, south, west, and north of Fujian Province [18], which can well reflect the survival of malignant tumors in Fujian. During the study, we strictly implemented relevant standards of data collection to guarantee the integrity and reliability of the data. Our results can be considered as baseline data for cancer survival studies in Fujian Province.

Our study showed that from 2012 to 2014, the 5-year relative survival of cancer patients in Fujian Province was $36.19 \%$. The age-standardized 5-year relative survival of patients in Fujian was 31.8\%, which was lower than Zeng's assessment of the relative survival of malignant tumors in China from 2012 to 2015 (40.5\%) [19]. There may be two reasons for the difference in relative survival between Fujian Province and China. Firstly, all the 17 registries in Zeng's study had carried out population-based cancer registration and
Table 2. The 5-year relative survival of patients stratified by areas.

\begin{tabular}{lccc}
\hline Area & Cases & Crude RS (95\% CI) & Adjusted RS (95\% CI) \\
\hline $\begin{array}{l}\text { Urban } \\
\text { Male }\end{array}$ & 8,440 & $28.88(27.83-29.93)$ & $27.68(26.60-28.78)$ \\
$\quad$ Female & 5,665 & $46.50(45.12-47.86)$ & $39.40(37.99-40.82)$ \\
$\quad$ Total & 14,105 & $36.05(35.21-36.90)$ & $32.34(31.49-33.20)$ \\
Rural & & & \\
$\quad$ Male & 10,955 & $28.47(27.56-29.38)$ & $26.39(25.45-27.34)$ \\
$\quad$ Female & 6,929 & $48.38(47.15-49.60)$ & $38.47(37.17-39.76)$ \\
$\quad$ Total & 17,884 & $36.28(35.53-37.03)$ & $31.29(30.53-32.06)$ \\
Urban and rural & & & \\
$\quad$ Male & 19,395 & $28.65(27.97-29.34)$ & $27.00(26.28-27.71)$ \\
$\quad$ Female & 12,594 & $47.55(46.63-48.46)$ & $38.90(37.95-39.85)$ \\
$\quad$ Total & 31,989 & $36.19(35.63-36.75)$ & $31.80(31.23-32.37)$ \\
\hline Abreviations: RS & Relative & &
\end{tabular}

Abbreviations: RS - Relative Survival

follow-up projects for a long time [20, 21]. In these projects, a large number of health education activities had been carried out by governments to improve the level of cancer prevention and treatment for these areas. Secondly, the composition of cancer was different between Fujian Province and China. The cancers of lung, gastric, liver, colorectal, and esophageal were the five most common cancers in Fujian Province. The 5 -year relative survival of all these cancers was lower than $50 \%$. The age-standardized survival of cancers in Fujian Province is standardized by taking the composition ratio of various cancers in China as the standard. After standardized by the national cancer types, the age-standardized 5-year relative survival of cancer in Fujian Province is 34.3\%, which is higher than the age-standardized relative survival without national cancer types' standardization. The survival of cancer in Fujian Province is greatly influenced by the composition of common cancer. Except for five common malignant tumors, nasopharyngeal carcinoma has the highest proportion among males. The relative survival of male patients with nasopharyngeal carcinoma in Fujian Province was $50.7 \%$, which was higher than that of the national average in China (42.2\%). Fujian Province has carried out screening for nasopharyngeal cancer for a long time. Precise treatment can reduce the cost of treatment and improve the survival rate of patients [22]. For females, the incidence rate of breast cancer is the highest in both areas. Compared with the national average, the age-standardized 5-year relative survival for breast cancer in Fujian Province is at a lower level $(82.0 \%$ vs. $70.4 \%$ ). One study had found that the therapeutic effect on early-stage breast cancer patients was significantly better than that of patients with advanced breast cancer [23]. Fujian Province needs to conduct more early-cancer screening and treatment programs to improve patients' survival.

Several regions in China are known to have a large disease burden of digestive cancers [24]. Fujian Province has also been considered as one of the high-risk areas of gastric cancer or liver cancer. In our study, the age-standardized 5-year relative survival of gastric cancer and liver cancer in Fujian 
Table 3. The 5-year relative survival of each type of cancer.

\begin{tabular}{|c|c|c|c|c|c|c|c|c|}
\hline \multirow[b]{2}{*}{ Cancer } & \multirow{2}{*}{\multicolumn{2}{|c|}{ Cases (\%) }} & \multicolumn{2}{|c|}{ All } & \multicolumn{2}{|c|}{ Male } & \multicolumn{2}{|c|}{ Female } \\
\hline & & & $\begin{array}{c}\text { Crude RS } \\
(95 \% \mathrm{CI})\end{array}$ & $\begin{array}{c}\text { Adjusted RS } \\
(95 \% \mathrm{CI})\end{array}$ & $\begin{array}{c}\text { Crude RS } \\
(95 \% \mathrm{CI})\end{array}$ & $\begin{array}{c}\text { Adjusted RS } \\
(95 \% \mathrm{CI})\end{array}$ & $\begin{array}{l}\text { Crude RS } \\
(95 \% \mathrm{CI})\end{array}$ & $\begin{array}{c}\text { Adjusted RS } \\
(95 \% \mathrm{CI})\end{array}$ \\
\hline $\begin{array}{l}\text { Oral cavity } \\
\text { and pharynx }\end{array}$ & 381 & $(1.19)$ & $\begin{array}{c}43.86 \\
(38.54-49.09)\end{array}$ & $\begin{array}{c}37.98 \\
(32.16-43.76)\end{array}$ & $\begin{array}{c}35.94 \\
(29.92-42.05)\end{array}$ & $\begin{array}{c}30.48 \\
(23.84-37.36)\end{array}$ & $\begin{array}{c}62.09 \\
(51.91-71.03)\end{array}$ & $\begin{array}{c}54.34 \\
(43.51-63.95)\end{array}$ \\
\hline Nasopharynx & 715 & $(2.24)$ & $\begin{array}{c}58.11 \\
(54.25-61.79)\end{array}$ & $\begin{array}{c}51.28 \\
(47.38-55.05)\end{array}$ & $\begin{array}{c}56.95 \\
(52.46-61.22)\end{array}$ & $\begin{array}{c}50.70 \\
(46.08-55.12)\end{array}$ & $\begin{array}{c}61.60 \\
(53.85-68.50)\end{array}$ & $\begin{array}{c}52.32 \\
(45.53-58.67)\end{array}$ \\
\hline Esophagus & 2,325 & $(7.27)$ & $\begin{array}{c}20.47 \\
(18.75-22.25)\end{array}$ & $\begin{array}{c}18.97 \\
(17.25-20.77)\end{array}$ & $\begin{array}{c}21.03 \\
(19.04-23.09)\end{array}$ & $\begin{array}{c}18.95 \\
(16.91-21.07)\end{array}$ & $\begin{array}{c}18.69 \\
(15.37-22.29)\end{array}$ & $\begin{array}{c}21.83 \\
(17.82-26.11)\end{array}$ \\
\hline Stomach & 4,459 & $(13.94)$ & $\begin{array}{c}31.23 \\
(29.77-32.70)\end{array}$ & $\begin{array}{c}29.49 \\
(28.09-30.91)\end{array}$ & $\begin{array}{c}30.97 \\
(29.26-32.71)\end{array}$ & $\begin{array}{c}29.12 \\
(27.43-30.84)\end{array}$ & $\begin{array}{c}31.89 \\
(29.14-34.69)\end{array}$ & $\begin{array}{c}31.10 \\
(28.48-33.75)\end{array}$ \\
\hline Colon-rectum & 3,480 & $(10.88)$ & $\begin{array}{c}46.45 \\
(44.62-48.27)\end{array}$ & $\begin{array}{c}45.10 \\
(43.20-46.98)\end{array}$ & $\begin{array}{c}46.76 \\
(44.35-49.15)\end{array}$ & $\begin{array}{c}45.85 \\
(43.27-48.39)\end{array}$ & $\begin{array}{c}46.00 \\
(43.18-48.79)\end{array}$ & $\begin{array}{c}44.59 \\
(41.76-47.37)\end{array}$ \\
\hline Liver & 4,154 & (12.99) & $\begin{array}{c}12.48 \\
(11.45-13.55)\end{array}$ & $\begin{array}{c}10.65 \\
(9.61-11.75)\end{array}$ & $\begin{array}{c}12.46 \\
(11.31-13.67)\end{array}$ & $\begin{array}{c}10.61 \\
(9.33-11.97)\end{array}$ & $\begin{array}{c}12.56 \\
(10.38-14.95)\end{array}$ & $\begin{array}{c}11.65 \\
(9.61-13.91)\end{array}$ \\
\hline Gallbladder & 300 & $(0.94)$ & $\begin{array}{c}20.92 \\
(16.23-26.08)\end{array}$ & $\begin{array}{c}21.00 \\
(16.28-26.13)\end{array}$ & $\begin{array}{c}18.48 \\
(12.42-25.63)\end{array}$ & $\begin{array}{c}19.01 \\
(12.75-26.23)\end{array}$ & $\begin{array}{c}23.50 \\
(16.64-31.12)\end{array}$ & $\begin{array}{c}21.95 \\
(15.70-28.88)\end{array}$ \\
\hline Pancreas & 487 & $(1.52)$ & $\begin{array}{c}7.41 \\
(5.19-10.15)\end{array}$ & $\begin{array}{c}6.73 \\
(4.67-9.28)\end{array}$ & $\begin{array}{c}7.24 \\
(4.58-10.72)\end{array}$ & $\begin{array}{c}6.49 \\
(4.01-54.62)\end{array}$ & $\begin{array}{c}7.71 \\
(4.21-12.64)\end{array}$ & $\begin{array}{c}7.10 \\
(3.86-11.65)\end{array}$ \\
\hline Larynx & 209 & $(0.65)$ & $\begin{array}{c}49.77 \\
(42.26-56.98)\end{array}$ & $\begin{array}{c}45.84 \\
(38.62-52.76)\end{array}$ & $\begin{array}{c}51.44 \\
(43.72-58.80)\end{array}$ & $\begin{array}{c}47.55 \\
(40.10-54.62)\end{array}$ & $--^{\mathrm{a}}$ & $--^{\mathrm{a}}$ \\
\hline Lung & 5,461 & $(17.07)$ & $\begin{array}{c}15.33 \\
(14.32-16.37)\end{array}$ & $\begin{array}{c}14.98 \\
(13.96-16.04)\end{array}$ & $\begin{array}{c}13.44 \\
(12.32-14.62)\end{array}$ & $\begin{array}{c}13.36 \\
(12.17-14.60)\end{array}$ & $\begin{array}{c}19.94 \\
(17.90-22.07)\end{array}$ & $\begin{array}{c}19.33 \\
(17.27-21.47)\end{array}$ \\
\hline Other thoracic organs & 71 & $(0.22)$ & $\begin{array}{c}40.65 \\
(28.71-52.49)\end{array}$ & $\begin{array}{c}34.45 \\
(22.65-46.54)\end{array}$ & $\begin{array}{c}23.79 \\
(11.78-38.44)\end{array}$ & $\begin{array}{c}16.93 \\
(8.27-28.20)\end{array}$ & $\begin{array}{c}63.36 \\
(42.72-79.16)\end{array}$ & $\begin{array}{c}60.79 \\
(41.78-75.29)\end{array}$ \\
\hline Bone & 180 & $(0.56)$ & $\begin{array}{c}27.96 \\
(21.35-35.00)\end{array}$ & $\begin{array}{c}29.05 \\
(22.33-36.10)\end{array}$ & $\begin{array}{c}31.01 \\
(21.87-40.78)\end{array}$ & $\begin{array}{c}32.45 \\
(22.52-42.76)\end{array}$ & $\begin{array}{c}24.08 \\
(15.11-34.28)\end{array}$ & $\begin{array}{c}21.72 \\
(14.34-30.09)\end{array}$ \\
\hline Melanoma of skin & 41 & $(0.13)$ & $\begin{array}{c}46.86 \\
(30.48-62.16)\end{array}$ & $\begin{array}{c}47.66 \\
(32.31-61.51)\end{array}$ & $\begin{array}{c}45.47 \\
(23.26-66.10)\end{array}$ & $\begin{array}{c}43.28 \\
(25.86-59.54)\end{array}$ & $\begin{array}{c}48.32 \\
(24.82-69.48)\end{array}$ & $\begin{array}{c}50.61 \\
(26.07-70.83)\end{array}$ \\
\hline Breast & 1,776 & $(5.55)$ & $\begin{array}{c}75.19 \\
(73.00-77.24)\end{array}$ & $\begin{array}{c}70.07 \\
(64.95-74.60)\end{array}$ & - & - & $\begin{array}{c}75.15 \\
(72.96-77.22)\end{array}$ & $\begin{array}{c}70.37 \\
(65.24-74.89)\end{array}$ \\
\hline Cervix & 887 & $(2.77)$ & $\begin{array}{c}68.57 \\
(65.31-71.60)\end{array}$ & $\begin{array}{c}64.01 \\
(59.04-68.53)\end{array}$ & - & - & $\begin{array}{c}68.57 \\
(65.31-71.60)\end{array}$ & $\begin{array}{c}64.01 \\
(59.04-68.53)\end{array}$ \\
\hline Uterus & 495 & $(1.55)$ & $\begin{array}{c}68.30 \\
(63.85-72.36)\end{array}$ & $\begin{array}{c}68.66 \\
(61.80-74.55)\end{array}$ & - & - & $\begin{array}{c}68.30 \\
(63.85-72.36)\end{array}$ & $\begin{array}{c}68.66 \\
(61.80-74.55)\end{array}$ \\
\hline Ovary & 338 & $(1.06)$ & $\begin{array}{c}51.51 \\
(45.93-56.82)\end{array}$ & $\begin{array}{c}45.72 \\
(40.87-50.43)\end{array}$ & - & - & $\begin{array}{c}51.51 \\
(45.93-56.82)\end{array}$ & $\begin{array}{c}45.72 \\
(40.87-50.43)\end{array}$ \\
\hline Prostate & 441 & $(1.38)$ & $\begin{array}{c}57.97 \\
(51.89-63.91)\end{array}$ & $\begin{array}{c}52.15 \\
(45.64-58.25)\end{array}$ & $\begin{array}{c}57.97 \\
(51.89-63.91)\end{array}$ & $\begin{array}{c}52.15 \\
(45.64-58.25)\end{array}$ & - & - \\
\hline Testis & 23 & $(0.07)$ & $\begin{array}{c}75.42 \\
(51.96-89.12)\end{array}$ & $\begin{array}{c}72.87 \\
(63.82-80.01)\end{array}$ & $\begin{array}{c}75.42 \\
(51.96-89.12)\end{array}$ & $\begin{array}{c}72.87 \\
(63.82-80.01)\end{array}$ & - & - \\
\hline Kidney & 442 & $(1.38)$ & $\begin{array}{c}59.46 \\
(54.27-64.38)\end{array}$ & $\begin{array}{c}54.08 \\
(48.13-59.66)\end{array}$ & $\begin{array}{c}57.67 \\
(51.12-63.85)\end{array}$ & $\begin{array}{c}53.74 \\
(46.33-60.58)\end{array}$ & $\begin{array}{c}62.94 \\
(54.27-70.67)\end{array}$ & $\begin{array}{c}55.22 \\
(44.81-64.44)\end{array}$ \\
\hline Bladder & 417 & $(1.30)$ & $\begin{array}{c}61.99 \\
(56.32-67.35)\end{array}$ & $\begin{array}{c}62.06 \\
(56.68-66.97)\end{array}$ & $\begin{array}{c}62.07 \\
(55.69-68.09)\end{array}$ & $\begin{array}{c}62.70 \\
(56.61-68.19)\end{array}$ & $\begin{array}{c}61.58 \\
(48.81-72.65)\end{array}$ & $\begin{array}{c}57.25 \\
(45.13-67.64)\end{array}$ \\
\hline Brain & 741 & $(2.32)$ & $\begin{array}{c}43.77 \\
(40.00-47.50)\end{array}$ & $\begin{array}{c}42.84 \\
(39.08-46.54)\end{array}$ & $\begin{array}{c}37.58 \\
(32.39-42.80)\end{array}$ & $\begin{array}{c}36.77 \\
(31.57-41.97)\end{array}$ & $\begin{array}{c}49.80 \\
(44.40-55.02)\end{array}$ & $\begin{array}{c}48.67 \\
(43.31-53.81)\end{array}$ \\
\hline Thyroid & 1,128 & $(3.53)$ & $\begin{array}{c}95.37 \\
(93.73-96.70)\end{array}$ & $\begin{array}{c}88.07 \\
(83.44-91.47)\end{array}$ & $\begin{array}{c}94.38 \\
(89.97-97.46)\end{array}$ & $\begin{array}{c}89.52 \\
(80.65-94.46)\end{array}$ & $\begin{array}{c}95.67 \\
(93.88-97.05)\end{array}$ & $\begin{array}{c}87.43 \\
(81.36-91.62)\end{array}$ \\
\hline Lymphoma & 652 & $(2.04)$ & $\begin{array}{c}45.56 \\
(41.47-49.59)\end{array}$ & $\begin{array}{c}38.69 \\
(34.23-43.13)\end{array}$ & $\begin{array}{c}43.47 \\
(38.08-48.81)\end{array}$ & $\begin{array}{c}37.94 \\
(31.94-43.90)\end{array}$ & $\begin{array}{c}48.40 \\
(42.10-54.46)\end{array}$ & $\begin{array}{c}40.39 \\
(33.67-46.99)\end{array}$ \\
\hline Leukemia & 604 & $(1.89)$ & $\begin{array}{c}37.58 \\
(33.59-41.58)\end{array}$ & $\begin{array}{c}34.72 \\
(30.86-38.60)\end{array}$ & $\begin{array}{c}39.50 \\
(34.18-44.81)\end{array}$ & $\begin{array}{c}37.40 \\
(32.27-42.52)\end{array}$ & $\begin{array}{c}34.91 \\
(28.94-40.95)\end{array}$ & $\begin{array}{c}31.04 \\
(25.38-36.85)\end{array}$ \\
\hline All others & 1,782 & $(5.57)$ & $\begin{array}{c}34.36 \\
(31.99-36.76)\end{array}$ & $\begin{array}{c}32.06 \\
(29.55-34.60)\end{array}$ & $\begin{array}{c}31.01 \\
(27.96-34.13)\end{array}$ & $\begin{array}{c}29.17 \\
(25.99-32.41)\end{array}$ & $\begin{array}{c}38.82 \\
(35.10-42.54)\end{array}$ & $\begin{array}{c}36.42 \\
(32.34-40.51)\end{array}$ \\
\hline
\end{tabular}

Notes: aThere are too few females with laryngeal cancer [9], which cannot represent the relative survival of female laryngeal cancer patients in Fujian Province. Abbreviations: RS-Relative Survival 
Table 4. The age-standardized 5-year relative survival of five common cancers in urban and rural areas.

\begin{tabular}{|c|c|c|c|c|c|c|}
\hline \multirow{2}{*}{ Cancer } & \multicolumn{3}{|c|}{ Urban } & \multicolumn{3}{|c|}{ Rural } \\
\hline & Cases & \multicolumn{2}{|c|}{ Adjusted RS (95\% CI) } & Cases & \multicolumn{2}{|c|}{ Adjusted RS (95\% CI) } \\
\hline Male & 1,632 & 13.04 & $(11.24-14.97)$ & 2,259 & 13.59 & $(12.03-15.23)$ \\
\hline Female & 691 & 17.59 & $(14.64-20.76)$ & 879 & 20.95 & $(18.06-23.99)$ \\
\hline Total & 2,323 & 14.11 & $(12.61-15.69)$ & 3,138 & 15.63 & $(14.25-17.08)$ \\
\hline \multicolumn{7}{|l|}{ Stomach } \\
\hline Male & 1,455 & 30.25 & $(27.67-32.87)$ & 1,790 & 28.16 & $(25.92-30.43)$ \\
\hline Female & 567 & 33.48 & $(29.55-37.45)$ & 647 & 28.64 & $(25.19-32.17)$ \\
\hline Total & 2,022 & 30.78 & $(28.67-32.92)$ & 2,437 & 28.39 & $(26.52-30.28)$ \\
\hline \multicolumn{7}{|l|}{ Liver } \\
\hline Male & 1,306 & 10.74 & $(8.83-12.87)$ & 1,973 & 10.46 & $(8.82-12.27)$ \\
\hline Female & 378 & 14.93 & (11.45-18.85) & 497 & 9.48 & $(7.10-12.26)$ \\
\hline Total & 1,684 & 11.54 & $(9.89-13.32)$ & 2,470 & 10.03 & $(8.72-11.45)$ \\
\hline \multicolumn{7}{|c|}{ Colon-rectum } \\
\hline Male & 933 & 45.64 & $(41.81-49.38)$ & 1,149 & 45.83 & $(43.34-49.25)$ \\
\hline Female & 635 & 43.31 & $(39.08-47.47)$ & 763 & 45.61 & $(41.78-49.35)$ \\
\hline Total & 1,568 & 44.15 & $(41.33-46.93)$ & 1,912 & 45.62 & $(43.04-48.16)$ \\
\hline \multicolumn{7}{|l|}{ Esophagus } \\
\hline Male & 863 & 20.41 & $(17.35-23.65)$ & 906 & 17.61 & $(14.97-20.43)$ \\
\hline Female & 303 & 24.64 & $(19.24-30.40)$ & 253 & 17.40 & $(12.84-22.55)$ \\
\hline Total & 1,166 & 20.66 & $(18.13-23.31)$ & 1,159 & 17.23 & $(14.94-19.65)$ \\
\hline
\end{tabular}

Abbreviations: RS - Relative Survival
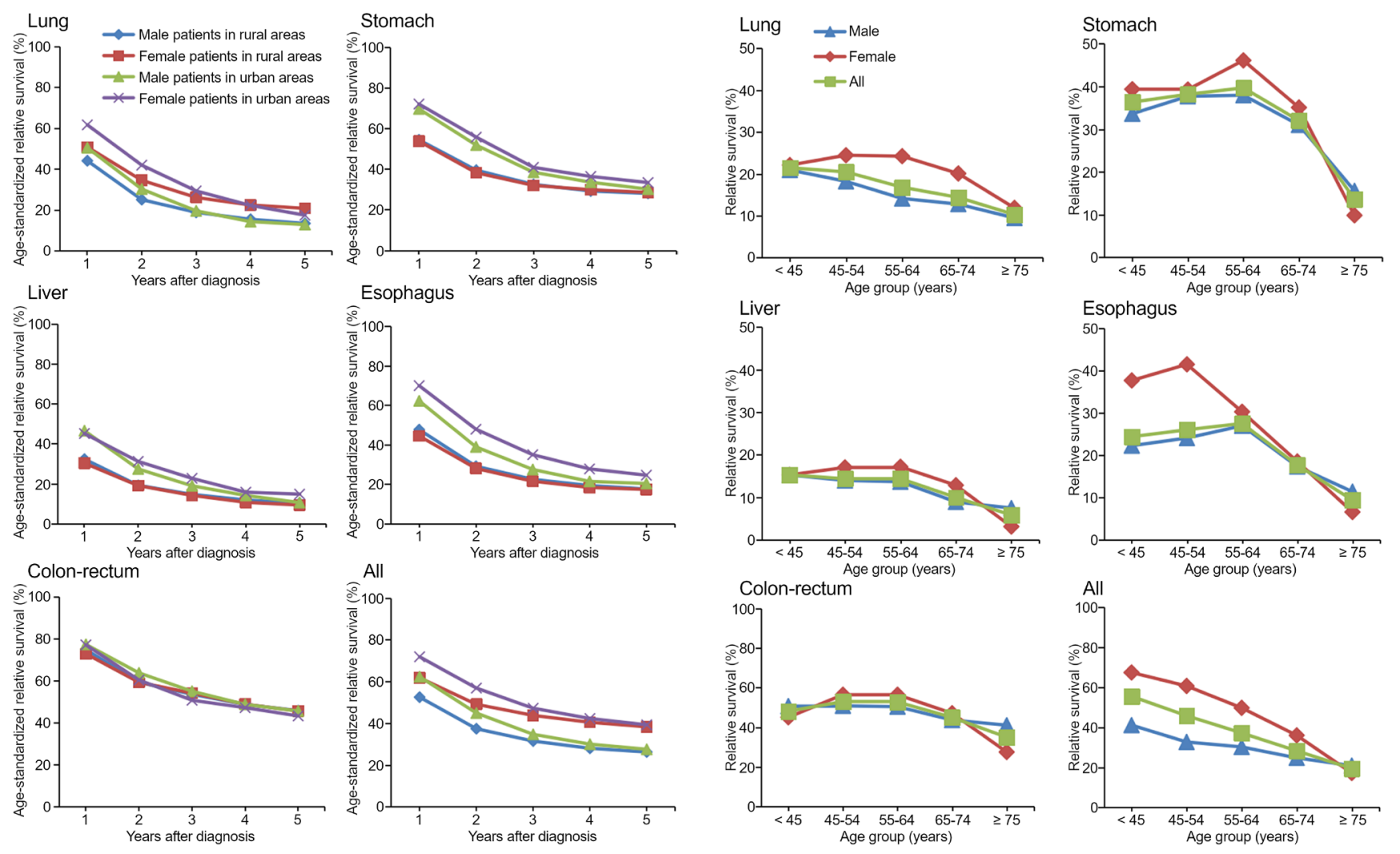

Figure 1. The survival curves for five common cancers.

Figure 2. The 5-year relative survival for five common cancers by age groups. 
both were lower than the national average. The prognosis of advanced patients with these two types of cancer is poor. Therefore, early prevention is especially important for these two types of cancers. Due to the high incidence of gastric cancer, Fujian Province has carried out field epidemiology study in Changle County. The results showed that Helicobacter pylori infection was an important factor to promote the occurrence of gastric cancer [25]. After improving some environmental factors, the infection rate of Helicobacter pylori in the population decreased, and the incidence of gastric cancer showed a downward trend at the same time. An unhealthy diet and hepatitis B virus infection are related to liver cancer. Timely vaccination and maintaining a healthy diet can reduce the occurrence of liver cancer $[26,27]$. In recent years, multidisciplinary cooperation treatment has promoted the therapeutic effect and improved the prognosis of patients with gastric cancer and liver cancer [28].

In our study, the relative survival in urban areas of Fujian Province is slightly higher than that in rural areas (1.05\%). This difference is smaller than Zeng's assessment of China. The difference can be explained as follows. Firstly, in recent years, the government has strengthened the publicity of the prevention and treatment of cancers, so that people in rural areas can know what malignant tumors are and how to protect themselves. Secondly, the government has increased the proportion of reimbursement of medical expenses. Therefore, patients in rural areas will not delay treatment or give up treatment because of medical expenses. Finally, due to increasingly convenient transportation, more and more patients from rural areas come to urban areas for treatment, where they can get better treatment regimens. The survival of cancers in urban and rural areas of Fujian Province still low. Therefore, the survival of urban and rural in Fujian Province should be improved at the same time.

This is the first study to report population-based cancer survival data in Fujian Province. Our study has some strengths. First, all 8 cancer registries use both active and passive follow-up to obtain patient survival information. If only passive follow-up is used during the study, some information may be inaccurate. Loss to follow-up will cause overestimation or underestimation of the real survival [29]. Active follow-up can reduce the impact of follow-up bias and provide accurate survival data. Second, relative survival was used to estimate the prognosis of patients in this study. Compared with the observed survival, the relative survival can better describe the prognosis of population-based cancer [30]. However, this study has some limitations. We have not obtained high-quality and high-proportion of cancer stage information, which limits the ability to perform further subgroup analysis of cancer-based on stages. We plan to require every registry in Fujian Province to provide detailed information about cancer stages in the future.

In summary, the disease burden of patients diagnosed with cancer in Fujian Province is significantly heavy at present, specifically for digestive cancers. Therefore, more attention should be paid to the prevention and treatment of digestive cancers. Early health education, screening, and multidisciplinary cooperation are significantly effective for cancer treatment and should be implemented for a long time.

Acknowledgments: This study was supported by the Fujian Provincial Health Technology Project (Grant number: 2018-ZQN-17).

\section{References}

[1] GLOBAL BURDEN OF DISEASE CANCER COLLABORATION, FITZMAURICE C, ABATE D, ABBASI N, ABBASTABAR $\mathrm{H}$ et al. Global, Regional, and National Cancer Incidence, Mortality, Years of Life Lost, Years Lived With Disability, and Disability-Adjusted Life-Years for 29 Cancer Groups, 1990 to 2017: A Systematic Analysis for the Global Burden of Disease Study. JAMA Oncol 2019; 5: 1749-1768. https://doi.org/10.1001/jamaoncol.2019.2996

[2] FARQUHAR DR, CONIGLIO AJ, MASOOD MM, LENZE $\mathrm{N}, \mathrm{BRENNAN} P$ et al. Evaluation of pathologic staging using number of nodes in p16-negative head and neck cancer. Oral oncol 2020; 108: 104800. https://doi.org/10.1016/j.oraloncology.2020.104800

[3] POURVAKHSHOORI N, KHANKEH HR, STUECK M, FARROKHI M. The association between air pollution and cancers: controversial evidence of a systematic review. Environ Sci Pollut Res Int 2020; 20: 10377-10386. https://doi. org/10.1007/s11356-020-10377-Z

[4] WEI W, ZENG H, ZHENG R, ZHANG S, AN L et al. Cancer registration in China and its role in cancer prevention and control. Lancet Oncol 2020; 21: e342-e349. https://doi. org/10.1016/S1470-2045(20)30073-5

[5] MIAO H, VERKOOIJEN HM, CHIA KS, BOUCHARDY C, PUKKALA E et al. Incidence and outcome of male breast cancer: an international population-based study. J Clin Oncol 2011; 29: 4381-4386. https://doi.org/10.1200/ JCO.2011.36.8902

[6] ZENG H, ZHENG R, GUO Y, ZHANG S, ZOU X et al. Cancer survival in China, 2003-2005: a population-based study. Int J Cancer 2015; 136: 1921-1930. https://doi.org/10.1002/ ijc. 29227

[7] DE ANGELIS R, SANT M, COLEMAN MP, FRANCISCI S, BAILI $P$ et al. Cancer survival in Europe 1999-2007 by country and age: results of EUROCARE-5-a populationbased study. Lancet Oncol 2014; 15: 23-34. https://doi. org/10.1016/S1470-2045(13)70546-1

[8] KACHURI L, DE P, ELLISON LF, SEMENCIW R, ADVISORY COMMITTEE ON CANADIAN CANCER STATISTICS. Cancer incidence, mortality and survival trends in Canada, 1970-2007. Chronic Dis Inj Can 2013; 33: 69-80.

[9] PARKIN DM, WHELAN SL, FERLAY J, TEPPO L, THOMAS DB. (Eds.). Cancer Incidence in Five Continents Volume VIII. IARC Scientific Publication No. 155, IARC, Lyon 2002, p.773. ISBN 9283221559

[10] BODE AM, DONG Z, WANG H. Cancer prevention and control: alarming challenges in China. Natl Sci Rev 2016; 3: 117-127. https://doi.org/10.1093/nsr/nwv054 
[11] ZHENG RS, SUN KX, ZHANG SW, ZENG HM, ZOU $\mathrm{XN}$ et al. [Report of cancer epidemiology in China, 2015.] Zhonghua Zhong Liu Za Zhi 2019; 41: 19-28. https://doi. org/10.3760/cma.j.issn.0253-3766.2019.01.005

[12] CURADO MP, EDWARDS B, SHIN HR, STORM H, FERLAY J et al. (Eds.). Cancer Incidence in Five Continents Volume IX. IARC Scientific Publication No. 160, IARC, Lyon 2007, p. 895. ISBN 9789283221609

[13] WEI KR, CHEN WQ, ZHANG SW, LIANG ZH, ZHENG RS et al. Cancer registration in the people's republic of China. Asian Pac J Cancer Prev 2012; 13: 4209-4214. https://doi. org/10.7314/apjcp.2012.13.8.4209

[14] CHIANG CL (Eds.). Introduction to Stochastic Processes in Biostatistics. Wiley, \& Sons, Inc., New York, London, Sydney 1968, p 301. https://doi.org/10.1002/bimj.19700120505

[15] EDERER F, HEISE H. (Eds.). Instructions to IBM 650 programers in processing survival computations: Methodological note No. 10, Bethesda, USA, 1959.

[16] ELANDT R, JOHNSON N. (Eds.). Survival models and data analysis (Wiley series in probability and mathematical statistics), Indianapolis, America, 1980.

[17] CORAZZIARI I, QUINN M, CAPOCACCIA R. Standard cancer patient population for age standardising survival ratios. Eur J Cancer 2004; 40: 2307-2316. https://doi. org/10.1016/j.ejca.2004.07.002

[18] FU W, CHEN Z, ZHU Z, LIU Q, VAN DEN BOSCH CCK et al. Spatial and Temporal Variations of Six Criteria Air Pollutants in Fujian Province, China. Int J Environ Res Public Health 2018; 15: 2846-2865. https://doi.org/10.3390/ ijerph15122846

[19] ZENG H, CHEN W, ZHENG R, ZHANG S, JI JS et al. Changing cancer survival in China during 2003-15: a pooled analysis of 17 population-based cancer registries. Lancet Glob Health 2018; 6: e555-e567. https://doi.org/10.1016/ S2214-109X(18)30127-X

[20] CHEN Q, LIU SZ, ZHANG SK, CAO XQ, LI BY et al. The relative survival and cure fraction of gastric cancer estimated through flexible parametric models using data from population-based cancer registration during 2003-2012 in Linzhou, China. Cancer Med 2020; 9: 2243-2251. https://doi. org/10.1002/cam4.2831
[21] HE Y, LI D, SONG G, LI Y, LIANG D et al. Lung cancer burden has increased during the last 40 years in Hebei Province, China. Thorac Cancer 2016; 7: 323-332. https://doi. org/10.1111/1759-7714.12331

[22] FEI Z, XU T, LI M, CHEN T, LI L et al. Effectiveness and costeffectiveness analysis of nimotuzumab for the radiotherapy of locoregionally advanced nasopharyngeal carcinoma. Radiat Oncol 2020; 15: 230-239. https://doi.org/10.1186/ s13014-020-01674-5

[23] JOKO-FRU WY, MIRANDA-FILHO A, SOERJOMATARAM I, EGUE M, AKELE-AKPO MT et al. Breast cancer survival in sub-Saharan Africa by age, stage at diagnosis and human development index: A population-based registry study. Int J Cancer 2020; 146: 1208-1218. https://doi. org/10.1002/ijc.32406

[24] CHEN W, ZHENG R, BAADE PD, ZHANG S, ZENG H et al. Cancer statistics in China, 2015. CA Cancer J Clin 2016; 66: 115-132. https://doi.org/10.3322/caac.21338

[25] WONG BC, LAM SK, CHING CK, HU WH, ONG LY et al. Seroprevalence of cytotoxin-associated gene A positive Helicobacter pylori strains in Changle, an area with very high prevalence of gastric cancer in south China. Aliment Pharmacol Ther 1999; 13: 1295-1302. https://doi.org/10.1046/ j.1365-2036.1999.00619.x

[26] SAGNELLI E, MACERA M, RUSSO A, COPPOLA N, SAGNELLI C. Epidemiological and etiological variations in hepatocellular carcinoma. Infection 2020; 48: 7-17. https://doi. org/10.1007/s15010-019-01345-y

[27] SIMON TG, CHAN AT. Lifestyle and environmental approaches for the primary prevention of hepatocellular carcinoma. Clin Liver Dis 2020; 24: 549-576. https://doi. org/10.1016/j.cld.2020.06.002

[28] CHANG SC, LIU KH, HUNG CY, TSAI CY, HSU JT et al. Adjuvant Chemotherapy Improves Survival in Stage III Gastric Cancer after D2 Surgery. J Cancer 2018; 9: 81-91. https:// doi.org/10.7150/jca.21989

[29] BRENNER H, HAKULINEN T. Implications of incomplete registration of deaths on long-term survival estimates from population-based cancer registries. Int J Cancer 2009; 125: 432-437. https://doi.org/10.1002/ijc.24344

[30] PARKER SL, TONG T, BOLDEN S, WINGO PA. Cancer statistics, 1996. CA Cancer J Clin 1996; 46: 5-27. https://doi. org/10.3322/canjclin.46.1.5 